\begin{tabular}{|l|l|l|}
\hline \multicolumn{2}{|c|}{ PublisherInfo } \\
\hline \hline PublisherName & $:$ & BioMed Central \\
\hline \hline PublisherLocation & $:$ & London \\
\hline \hline PublisherImprintName & $:$ & BioMed Central \\
\hline \hline
\end{tabular}

\title{
Role of the ATM protein in neurogenesis
}

\begin{tabular}{||l|l|l||}
\hline \multicolumn{2}{|c|}{ ArticleInfo } \\
\hline \hline ArticleID & $:$ & 4001 \\
\hline \hline ArticleDOI & $:$ & $10.1186 /$ gb-spotlight-20010306-02 \\
\hline \hline ArticleCitationID & $:$ & spotlight-20010306-02 \\
\hline \hline ArticleSequenceNumber & $:$ & 72 \\
\hline \hline ArticleCategory & $:$ & Research news \\
\hline ArticleFirstPage & $:$ & 1 \\
\hline \hline ArticleLastPage & $:$ & 2 \\
\hline \hline & & RegistrationDate : 2001-03-06 \\
ArticleHistory & $:$ & OnlineDate $\quad$ 2001-03-06 \\
\hline \hline ArticleCopyright & $:$ & BioMed Central Ltd2001 \\
\hline \hline ArticleGrants & $:$ & \\
\hline \hline ArticleContext & $:$ & 130592211 \\
\hline \hline
\end{tabular}




\section{Kenneth Lee}

Email: kenlee_fr@yahoo.fr

Ataxia telangiectasia (AT) is a recessive childhood disease caused by mutations in the ATM (ATmutated) gene. The hallmark of the disease is progressive neurodegeneration that eventually affects all areas of the brain. It is known that the ATM protein initiates a cascade of signalling events that leads to cell-cycle arrest and DNA repair in response to ionising radiation. Its role in the nervous system is not clear.

In the 1 March Genes and Development, researchers led by Carrolee Barlow of the Salk Institute for Biological Studies, La Jolla, California, report that neural progenitor cells lacking ATM show a blunted response to environmental stimuli that would normally result in proliferation, survival and differentiation along a neuronal lineage (Genes Dev 2001, 15:554-566).

They found that neuronal stem cells in the hippocampus of $A T M-/-$ mice had an abnormally high basal rate of proliferation. In wild-type mice, environmental stimulation, such as the use of an exercise wheel, led to an increase in the number of proliferative cells in the hippocampus as well as the number of these cells that survived as neurons. But in $A T M-/$ - mice, exercise led to a marked decrease in proliferation and neuronal differentiation. $A T M-/-$ cells that did differentiate into neurons showed reduced viability.

The findings suggest that ATM is essential for the development and differentiation of adult neuronal progenitor cells.

\section{References}

1. Salk Institute for Biological Studies, [http://www.salk.edu/]

2. Allen DM, van Praag H, Ray J, et al: Ataxia telangiectasia is essential during adult neurogenesis. Genes Dev 2001, 15:554-566., [http://www.genesdev.org/]

This PDF file was created after publication. 